\title{
Incongruent Waterworlds: Situating the Everyday Practices and Power of Water in Delhi
}

\section{Yaffa Truelove}

\section{(2) OpenEdition}

\section{Journals}

Electronic version

URL: http://journals.openedition.org/samaj/4164

DOI: $10.4000 /$ samaj.4164

ISSN: $1960-6060$

Publisher

Association pour la recherche sur l'Asie du Sud (ARAS)

Electronic reference

Yaffa Truelove, «Incongruent Waterworlds: Situating the Everyday Practices and Power of Water in Delhi », South Asia Multidisciplinary Academic Journal [Online], 14 | 2016, Online since 29 August 2016, connection on 18 April 2019. URL : http://journals.openedition.org/samaj/4164 ; DOI : 10.4000/ samaj.4164

This text was automatically generated on 18 April 2019

This work is licensed under a Creative Commons Attribution-NonCommercial-NoDerivatives 4.0 International License. 


\title{
Incongruent Waterworlds: Situating the Everyday Practices and Power of Water in Delhi
}

\author{
Yaffa Truelove
}

\section{Introduction}

1 In the early months of 2012, one of India's leading dailies ${ }^{1}$ published an article declaring the water problems were solved in a "slum" settlement called Rampur Camp2 in South Delhi. It praised an NGO-led initiative that helped a women's collective to confront the slum's lack of access to centralized municipal amenities including water and sanitation. Declaring the women's group an example of how, in conjunction with the NGO called Fluidworks, " a community initiative changes lives," the article highlighted the effort to "bring drinking water to hundreds of shanties" as an example of the success of local initiatives that supplant the government's lack of water and sanitation provisioning in slums. Working in tandem with a number of state bodies and agencies, Fluidworks declared the intervention had "improved living conditions for the community," including the installation of water pipes and the effective mobilization of the women's group around water and sanitation issues.

2 Part of a water and sanitation initiative in over 20 slums of Delhi, the water intervention in Rampur Camp occurred through the "Swach Delhi Swasth Delhi" (Clean Delhi Healthy Delhi) campaign. The local NGO Fluidworks orchestrated the implementation on the ground, which was jointly funded by WaterAid India, HSBC, and elected representatives (such as the South Delhi Municipal Councillor) representing Rampur Camp's constituency. In addition, Fluidworks involved state agencies like the Delhi Jal Board (DJB) and the Department of Urban Development. This regulatory arrangement can be situated within a "host of alternatives" (Bakker 2011:353) that have emerged in response to failures associated with both public deficiencies and privatizing water in the early 2000s across differing countries (also see Ranganthan 2014:591). In 2005, following the 
trend of a number of cities around the world, a movement against measures to privatize Delhi's water supply was successfully mobilized by Delhi's middle classes. However, the state's water board nonetheless continued to fail to provide adequate water for both poor residents (who were largely unconnected) and more elite inhabitants (who encountered unreliability and inequitable access). In 2011, the "Swach Delhi Swasth Delhi" (SDSD) program presented one alternative route to both governing and procuring water for slum-dwellers in its chosen 20 settlements, with the premise of involving the community, NGOs and the state in developing water alternatives that would be additionally funded by residents themselves.

Rather than implementing a uniform set of infrastructures at each site, the campaign considered the already existing variegated governance of water across Delhi's settlements, which is characterized by what Bakker (2003) calls "archipelagos" of access. The city's urban fabric is marked by highly fragmented systems of water regulation and access. In particular, historical (Sharan 2011; Mann 2007; Hosragrahar 1997) and contemporary studies of Delhi (Zérah 2000; Sheikh, Sharma and Banda 2015; Datta 2012; Baviskar 2003) have illuminated the dualisms of water governance and access between legal and illegal colonies. While legal colonies have official rights to connect to the state water supply, city-dwellers who live on illegal land lack these same rights, and highly differing geographies of coverage exist across the National Capital Territory (NCT) (Truelove 2015; CAG 2013). However, less has been discussed in the literature that problematizes and complicates overarching dualisms in the city's water supply to examine more finely-grained and diverse everyday practices of residents. For example, residents who have legal municipal connections nonetheless frequently struggle with unreliability and erratic access due to interruptions in supply, contamination, and problems of unequal distribution across zones and neighbourhoods (Zérah 2000; Truelove, under review). As a result, the middle and elite classes of Delhi's formal settlements heavily rely on differing informal and illegal water extraction technologies and practices that disrupt the association of legal colonies with legal water access (Daga 2003; Davis 2004; Truelove and Mawdsley 2011). In addition, dualisms of legal and illegal access also break down with regard to informal settlements, where hybrid state arrangements, elite control over water and concentrated forms of water exclusion position residents with highly diverse forms of water access and regulation that are too heterogeneous to generalize (Truelove 2015). In addition, there has been a relative dearth of studies that break apart water regulation and access within illegal (and legal) settlements to examine the situated and variegated governance of water, as well as its lived and embodied impacts. As aptly noted by Desai, McFarlane and Graham (2015), studies of the political ecology of water in cities has, as of yet, only given limited attention to the everyday practices and diverse embodied impacts of water infrastructures. They state (2014:7):

There is still limited scholarship in urban political ecology that explores people's everyday experiences and practices in relation to infrastructure and that deepens our understanding of the relationships between the body, infrastructure and the city.

The SDSD campaign in Rampur Camp, while purporting to provide community-wide benefits, presents an opportunity to tease apart the variegated governance and lived experiences of water in Delhi's informal settlements. While the metaphor of archipelagos of access (Bakker 2003) productively highlights inter-settlement islands that are characterized by spatially unique assemblages of access and control, research in Rampur 
Camp suggests that archipelagos themselves are characterized by intra-settlement spaces of differential regulation and practice, requiring a situated approach to uncover the uneven impacts and lived experiences of the city for residents.

Although the media and other organizations (including HSBC, WaterAid, and Fluidworks) proclaimed the uniform success of the SDSD initiative in Rampur Camp, many residents on the ground experienced not only a worsening of their water access-replacing treated tanker water with contaminated and saline tubewell water-but perhaps even more strikingly, a reconfiguration of power, authority, and embodied spatial practices. Tracing the water initiative in Rampur Camp from 2011-2012, this paper investigates the changing governance of water within the settlement, revealing how new political assemblages emerged to shape diverse forms of water provisioning. Rather than the conventional reading of the state as having "withdrawn" from water governance in illegal colonies-leaving a gap to be filled by NGOs, informal authorities, and alternate providers of water-my analysis reveals shifting state and non-state political assemblages as playing key roles in the everyday regulation of water in Delhi. In particular, I demonstrate that everyday governance is shaped by (re)configurations of particular nodes and networks of the state and other actors, which enable particular powers of reach and authority (Allen and Cochrane 2010) to be exercised in relation to water (see also Truelove, forthcoming submission). A situated approach brings attention to the unique formation of these political assemblages in relation to specific settlements in Delhi, helping to reveal why the governance of water is highly varied within and across settlements deemed as uniformly illegal and consequently excluded.

6 Second, I turn to an investigation of residents' diverse lived experiences of the water supply, both before and after the initiative. My findings detail the diverse ways water is continually (re-)negotiated, embodied, and socially differentiated on the ground, revealing plural political agencies, subjectivities and outcomes within informal settlements themselves. These findings ultimately serve to further break open the socalled "slum city," revealing situated and distributed forms of power in shaping incongruent urban environments for the city's residents. This paper thus advocates for a situated approach to the political ecologies of water in Delhi, in order to illuminate how the urban waterscape is tied to socially differentiated forms of power, authority, marginality, and precariousness that illuminate the fluid nature of urban lives.

7 Methodologically, this article draws on more than two years of ethnographic research from four extended field visits to Rampur Camp between the years of 2008-2012, as well as telephone follow-up interviews in 2013, and a subsequent field visit in 2016. I therefore draw on qualitative data that documents everyday experiences of water infrastructure as well as its temporal transformation. Specifically, during 2008, I first became acquainted with community members and families who had been living in Rampur camp and their daily lived experiences of water and sanitation (before the SDSD initiative examined in this paper). Through open-ended interviews, conversations and observations with community members, I documented the lived experiences of water inequality in the community, including the gendered forms of labour, physical hardship, and violence associated with accessing and managing water and sanitation (Truelove 2011). From 2011-2012, I began closely following an SDSD-led transformation of the local water supply, replacing state tanker deliveries with tubewell water. I conducted regular visits, observations, group discussions, open-ended interviews and informal conversations with over 60 community members. Residents were spread across both the predominately 
Hindu and predominately Muslim areas of the settlement, and also included differing caste groups, as well as both men and women. In addition, interviews with 10 key informants, including NGO leaders, Delhi Jal Board employees and local politicians, allowed me to temporally track the regulation, everyday practices, encounters, and meanings associated with the local water intervention.

\section{Situating UPE in Delhi: Pluralized Practices, Power, and Water Infrastructures}

8 There have been a number of recent scholarly calls over the last five years to "situate" urban political ecology (UPE) (Lawhon, Ernstson and Silver 2014; Truelove 2011; Graham and McFarlane 2014; Zimmer 2015; Loftus 2012). Although the UPE framework is quite broad (and this article will not attempt to repeat the excellent reviews of its scholarly lineage (see for example, Zimmer (2010) and Kiel (2003, 2005)), scholars have demonstrated the analytical need for UPE to de-centre a dominant focus on class relations and capital as the overarching forces structuring power and inequality associated with socio-natural transformations in cities (Lawhon et al. 2014; Truelove 2011; Rocheleau, Thomas-Slayter and Wangari 2013). UPE's lineage and originating focus stems from Marxist roots, arising from a foundational interest in how labour and technology serve to co-produce nature. As such, Marxism has provided an important underpinning for the framework's focus on how power operates. The socio-natural transformation of cities through the metabolic urbanizing of resources like water, electricity, and concrete thus provides a lens to unpack how such resources are tied to social power relations and inequality (Lawhon et al. 2014:500; Swyngedouw 2004; Heynen, Kaika and Swyngedouw 2006; Loftus 2012).

9 However, recent research reveals the need to complicate Marxist (and other theoretical orientations such as post-structural and STS-inspired approaches to UPE) in order to more fully account for the diverse forms and contexts of urbanism globally. In particular, a situated approach to UPE is poised to more distinctly account for the unique histories and trajectories of urbanism in Southern cities (Lawhon et al. 2014; Truelove 2015; Silver 2016; Zimmer 2010), diverse urban environments (McFarlane et al. forthcoming), and everyday practices and politics that produce uneven infrastructures and lived experiences for city-dwellers (Graham and McFarlane 2014; Truelove 2011; Loftus 2012; Birkenholtz 2010). For example, Lawhon et al. (2014) articulate how African urbanism can inform a "provincialized" UPE that is particularly attentive to how institutions, concepts, histories, and diverse power configurations uniquely shape the political ecologies of cities in heterogeneous ways. They state:

To provincialize UPE is to develop a way of framing that is more attentive to place and that can question taken-for-granted ideas in order to broaden the scope for theorizing with more urban experiences in mind. We refer to the outcome of this provincialization as a situated UPE (Lawhon et al. 2014:505).

Scholars utilizing this approach suggest that the heterogeneity that emerges through such a lens complicates and even disrupts more uniform readings of how social, environmental, and political power and inequality operate in cities.

With regard to the urban environment of postcolonial cities more specifically, a situated approach to UPE provides a platform to more fully account for and theorize these cities' unique infrastructural histories and processes of urban development. For example, Kooy 
and Bakker (2008), and Zérah (2008), have persuasively shown that neoliberal changes in governance have limited explanatory value with regard to the widespread fragmentation of urban infrastructures like water and electricity in cities like Jakarta and Mumbai. Instead, these scholars show that infrastructural fragmentation has been a norm, rather than exception, of city life since colonial times. Thus, the effects of initiatives to privatize amenities such as water or sewerage require a situated approach that is attentive to the uneven geographies of "archipelagos" (Bakker 2003) of access that predate neoliberal reforms and consequently shape their results. In addition, these contextual differences in infrastructural development present unique environmental, social and political consequences that require rigorous investigation, instead of assuming uniform or predictable outcomes (Pflieger and Matthieussent 2008).

11 In addition to bringing attention to Southern histories of postcolonial infrastructural fragmentation, a situated approach is also poised to more specifically delineate how a range of social power relations shapes and is produced through the infrastructural ecologies of the city. As demonstrated in Graham and McFarlane's volume Infrastructural Lives, the diverse ways that infrastructures shape everyday social life vary considerably across contexts (Graham and McFarlane 2015: kindle location 267). City-dwellers' lived experiences of infrastructures are both mediated through, and productive of, socioeconomic and cultural positions that include class, gender, race, and caste. These infrastructural experiences include the practices that the materiality of infrastructures necessitates, as well the ways "the politics of infrastructure can exclude and render a whole set of new responses in everyday life" (Graham and McFarlane 2015: kindle location 248).

With relation to water more specifically, Truelove (2011), Truelove and Mawdsley (2011), Datta (2012), Cornea et al. (forthcoming), Sultana (2009), O’Reilly (2010), Laurie (2005), Harris (2009), Birkenholtz (2013) and Desai, McFarlane and Graham (2015) investigate how gender and ethno-religious subjectivities are interpolated and re-produced by the practice and governance of water and sanitation. These studies reveal how the political ecology of water is connected to gendered constructions of public and private space (Datta 2012; Sultana 2009; Kaika 2004), ideologies of femininity and masculinity (Laurie 2005; O'Reilly 2006), the unequal codification and criminalization of informal water practices (Truelove and Mawdsley 2011; Kooy 2014), and embodied consequences of access and control that forge compounded forms of gendered and classed social exclusion in cities. This body of work further elucidates how water is tied up in social power relations that span scales and spaces, including households, lanes, neighbourhoods, "slums," cities, regions, and global networks. The diversity of political and ecological consequences of water resources necessitates bringing a more pluralized approach to the lived experiences, contexts, and politics of infrastructures, shifting from UPE to a study of what Zimmer (2010) calls multiple urban political ecologies.

This paper seeks to draw from, and extend, this body of knowledge by demonstrating how infrastructural transformations of the water supply in Delhi reveal everyday forms of power and politics that go beyond, and add complexity to, class and capital accumulation readings of the city. It contributes to an emerging body of work on urban water in India (see Björkman 2015; Anand 2011; Coelho 2006) that examines how networks, materials, and urban ecologies shape the configuration of the water supply and its lived consequences. For example, the insightful works of Björkman (2015) and Anand (2011) on Mumbai's water each show how infrastructures themselves embody configurations of 
materials, social relations and politics that produce uneven outcomes in the city. Björkman (2015) illuminates the speculative and impermanent nature of water pipes and politics in Mumbai's informal settlements such that pressure and access remains in a more or less constant state of change and flux. Similarly, Anand (2011) shows how technical, political, and geophysical pressure on the water supply shape the situated functioning of water systems with differentiated and uncertain outcomes for settlers. Building on this work, there remains a need to further tease apart intra-settlement archipelagos of regulation and their consequent impacts on city-dwellers. A situated approach to the political ecologies of water in cities thus provides a unifying framework to analyse both the diverse practices of the multiple institutions governing water, and differing embodied experiences of residents who share similar and/or distinct water spaces.

\section{Negotiating Water in Delhi: Infrastructural Archipelagos and Variegated Governance}

Delhi's water supply is highly fragmented both across and within its numerous colonies. Water inequality and unreliability is experienced by not only poorer populations, but by most income and social groups in the city to differing degrees. Rather than this phenomenon being a consequence of recent efforts to neoliberalize portions of the water supply, particularly through incremental public-private institutional arrangements, Delhi's water supply has been highly fragmented since at least early as the British colonists brought piped water to the city in the late 1800s. Colonial water development actively produced a waterscape that drastically differed from the "modern infrastructural ideal" (Graham and Marvin 2001) of universal coverage in European cities. Instead of seeking to formalize water access to the entirety of the population through a centralized grid, the colonial government lacked the political will to financially invest in universal coverage (Sharan 2006, 2011; Mann 2007; Hosagrahar 1997). As a result, colonial Delhi set in motion a distinctly informal water development trajectory that first and foremost served the colonists with privileged and segregated access to piped water (Sharan 2011). This segmented infrastructure required Indians to continuously rely on partial and piecemeal systems of access, including procuring water from wells, ponds, and private purchases (Sharan 2011). Thus, the "dual" colonial city was mapped and produced through the everyday unequal extension of its water supply.

Even when infrastructural systems were further developed and extended after India's Independence, "archipelagos" (Bakker 2003) of access across the capital territory became the norm, rather than exception, of Delhi's development. While residents in authorized or planned colonies were granted formal rights to piped water connections, lack of legality and legitimacy associated with informal settlements resulted in settler and unauthorized colonies being denied official rights to the city's centralized piped water infrastructure (Sheikh et al. 2015). However, dualistic readings of legal/illegal divides fail to capture the contradictions and hybrid water access experienced by many communities. For example, the state has nonetheless provisioned water in some form or another (including centralized access) to illegal populations despite not being legally obliged to do so, and those populations living on "legal" land sometimes lack central piped connections and face problems of chronic unreliability and sporadic contamination. This has led to a widespread practice among middle-class residents of illegally installing tubewells to 
supplement, or replace, centrally piped access (Daga 2003). Furthermore, some legal colonies lacked connections to the central water supply due to a lack of inter-agency coordination, inter-state water disputes, and/or the politics of planning, such as in the Dwarka case (Maria 2006). For illegal areas that are unable to access the central supply, some populations in these settlements access tubewell water that is negotiated and brokered through local politicians and ultimately distributed by the state, while most settlements often rely on a mixture of public and private tanker deliveries, standposts, and informal water networks. The everyday negotiations to procure water-sometimes involving local politicians and the Delhi Jal (water) Board, and other times the so-called water mafia, neighbours, employers, and nearby residential areas-is highly situated and leads to a set of uneven social and infrastructural effects within and across colonies.

\section{Infrastructural Variations and Practices in Delhi's Rampur Camp}

16 Against this wider historical backdrop of the uneven infrastructural fabric of the city, residents within Rampur Camp face a daily struggle to secure water for drinking, washing, and cooking purposes. Established approximately 30 years ago, the camp is a jhuggi jhopri (JJ) cluster, or small "illegal" settlement in the heart of South Delhi. ${ }^{4}$ It is directly adjacent to a relatively large and moderately affluent middle class authorized colony, where many women from the camp work as domestic cleaners and cooks. The men of the settlement tend to work (often sporadically) as labourers, repairmen, painters, and drivers. Houses, both pakka (made of concrete or solid walls) and kaccha (tents or more impermanent dwellings) have been slowly and painstakingly built through a series of bribes to local police, who exact regular fees for any new structure or wall built in the area. There is a very notable visual and audible difference across the camp's spatial geography (see Figures $1 \& 2$ ). The predominately Hindu side of the area visibly appears (in general) to be more built up, with larger paved lanes, a higher proportion of pakka homes. One hears Hindi spoken in a number of regional accents and dialects. On the other hand, the predominately Muslim side, which is notably smaller by comparison, has visibly less amenities (such as indoor light fixtures, fans, lights, and chairs) a greater quantity of partially pakka, partially kaccha, or entirely kaccha homes. The dominant language in this area of the settlement is a dialect of Bhojpuri associated with Northwest Bihar. 
Figure 1:

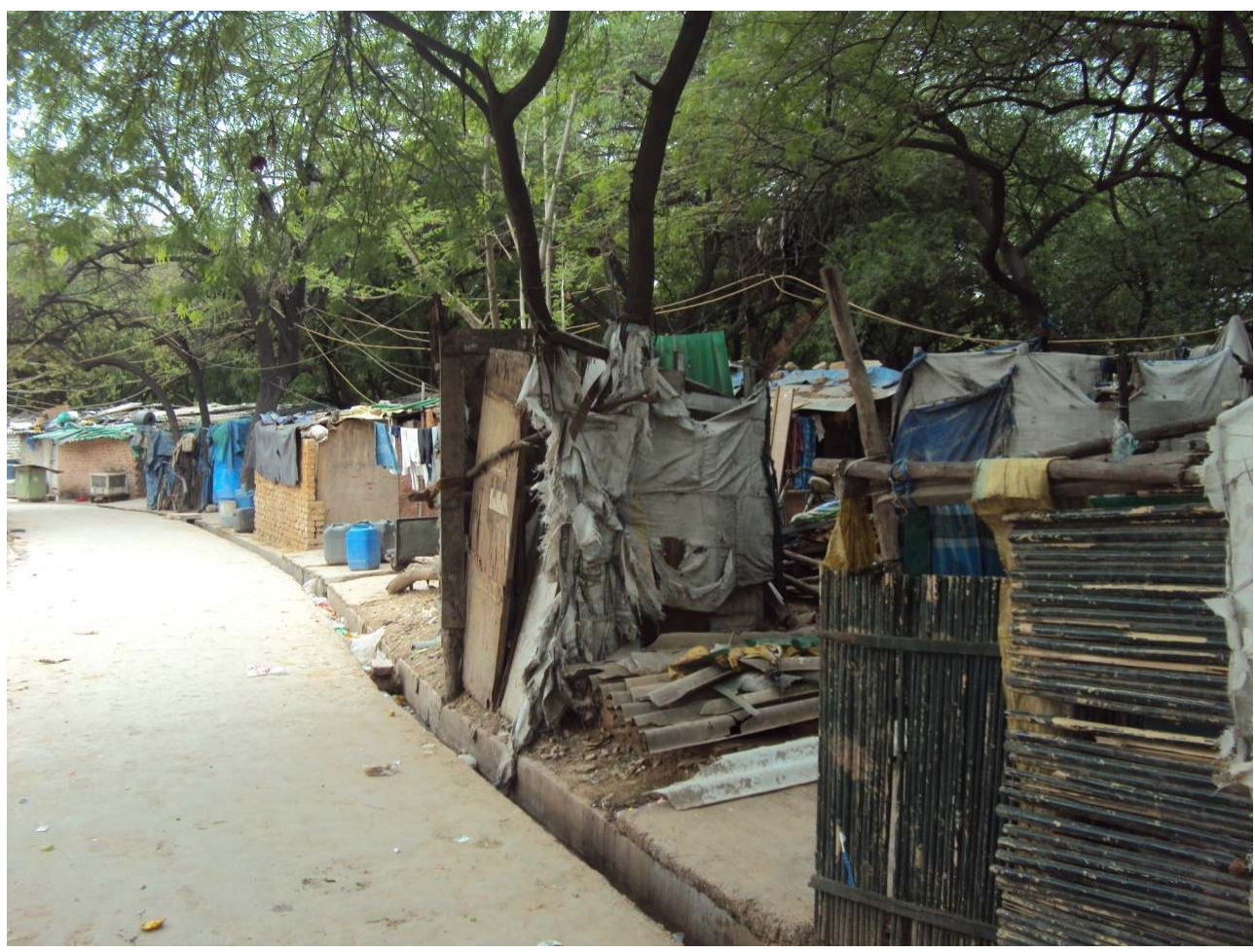

ENTRANCE TO PREDOMINATELY MUSLIM AREA OF RAMPUR CAMP

Figure 2:

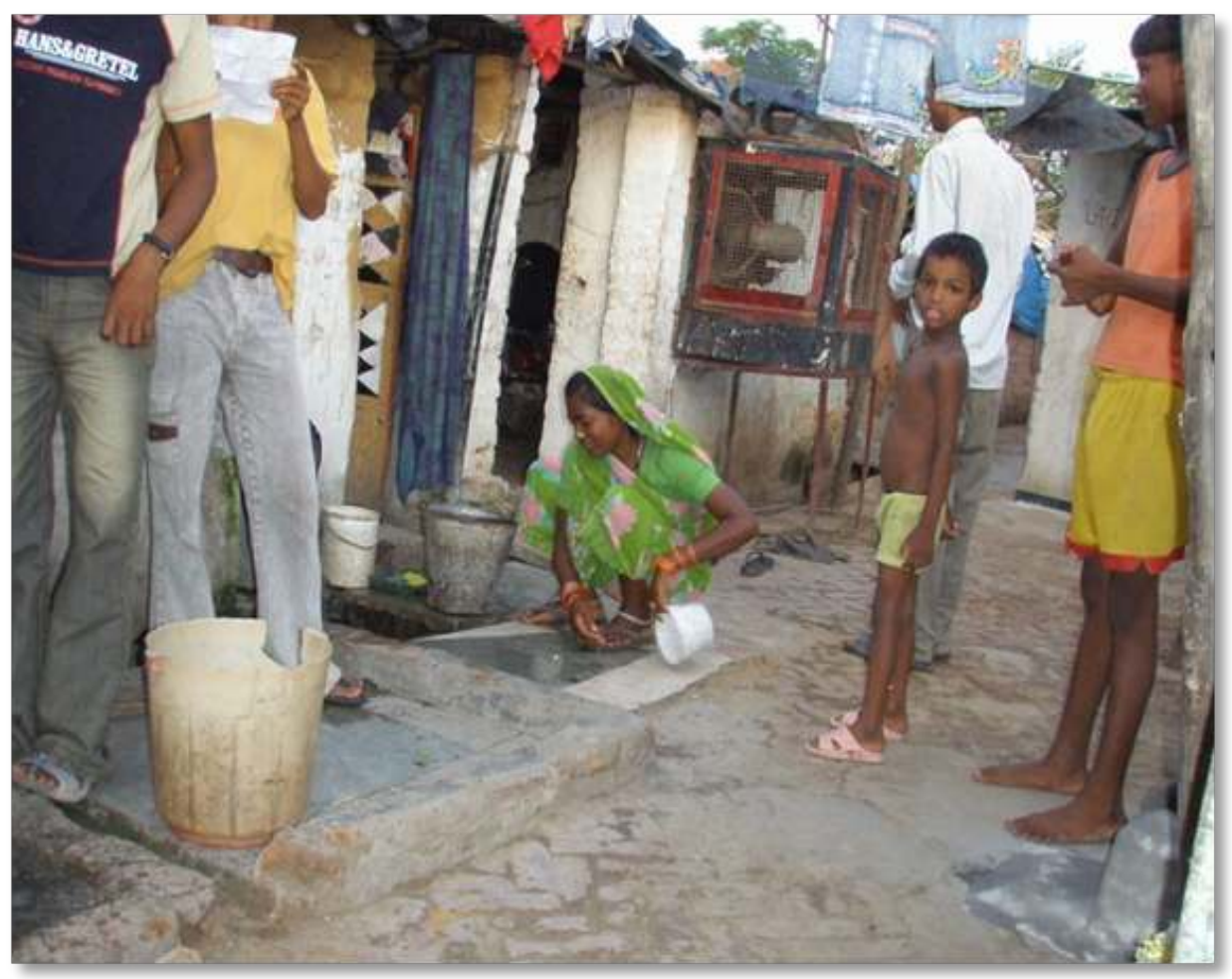

LANE IN PREDOMINATELY HINDU AREA OF RAMPUR CAMP 
17 Notably, my interviews revealed small numbers of Hindu residents who were earning incomes upward of Rs 2000-3000 per day, placing them in a more solidly middle class stratum. Such locals have been able to afford cars and start private businesses, to save money by staying in rent-free housing, or even lease parts of their individual plots to other families, boosting their monthly incomes to levels that are well within the middle class. These residents send their children to better schools, access water, sanitation and healthcare often through private purchases, and in general wield greater power within the community, bypassing or even exerting control over many of the infrastructure struggles of poorer residents. However, the majority of residents rely on a combination of government, private and NGO-initiated infrastructures and services that have been piecemeal and largely unreliable.

\section{Water Infrastructures Prior to 2011}

18 Prior to the SDSD initiative in 201l, official water provisioning in the settlement was limited to two state tanker deliveries per day (one to each side of the ethno-religiously divided camp). These tanker deliveries provided treated water, which could be used for drinking, cooking, and cleaning, but presented a number of problems and hardships for residents. When I first conducted research in the area in 2008, state tankers arrived inconsistently in the mornings, and provided water only to those residents who could quickly compete to fill buckets and containers. At the theoretical time of delivery, it was common to see residents (armed with multiple buckets and containers) waiting on the main road for the tanker's arrival, sometimes leaving disappointed when it failed to arrive (which occurred with greater frequency during summer months). When tankers would arrive, residents who lacked other family members or the help of neighbours had little opportunity to fill more than one container, if that. In addition, women often relied on children to help with this process, from scrambling on top of the tankers to place tubes to siphon the water, to carrying and helping to manage buckets. In everyday chatter, it was common to hear the lament that the tanker was typically "drained within five minutes," and this time was characterized as being a moment of chaos and scrambling for residents. This set of dynamics continued to be the case when I returned in 2009 as well as 2011, at the beginning of a SDSD water initiative in the area. If the tanker failed to come for days at a stretch, some residents would eventually go to the local DJB office to inquire and complain, occasionally leading to the tanker's arrival the following day. Over the years, residents reported also occasionally approaching the local Councillor and MLA, particularly a group of men who had gradually developed more links with local politicians.

19 In addition, as the delivery of state tanker water was split along the ethno-religious lines of the camp, I observed the predominately Hindu area as receiving more regular deliveries and a larger-sized tanker, which occasionally failed to arrive. The Muslim population (about $30 \%$ of the community) relied on a smaller tanker that, despite being scheduled to come daily, delivered water more sporadically. In both areas, the municipal tankers would arrive at varied times in the morning or afternoon, sometimes with multiple days passing without any delivery. As a result, Hindu and Muslim women who managed the gendered labour of water, along with solitary Muslim men (whose gendered water roles were reversed due to their wives remaining in rural areas), would sometimes stay back from work, as well as resort to buying and procuring water from alternate 
sources. One popular alternate water point was a neighbouring informal settlement that was approximately $3 \mathrm{~km}$ away-a walk that was highly dangerous (and thus usually prohibitive) for lone women (due to attacks and harassment on the street) and physically taxing for hauling water. Other residents frequently sought water from their employers in nearby middle-class homes. However, Muslim residents from the area were, overall, more reticent to approach the local DJB office or politicians. While many factors contributed to this hesitancy (including a lack of support from the Pradhan (informal local leader) of the area, and higher levels of reported "hopelessness" with the system), the men from the area who lived apart from their rural families also had more constraints on their time and labour as they had to accomplish both work and domestic tasks in any given day without the aid of other household members.

\section{Re-configuring Reach and Presence in the Governance of the Water Supply}

When the NGO Fluidworks first entered the settlement for the SDSD campaign in 2011, the NGO relied on national and globally stretched institutions and actors to support the initiative and later publicize its success in Rampur Camp. The SDSD campaign across 20 settlements was predominately funded by WaterAid. However, fluidworks also drew from donors like HSBC, and worked in conjunction with state representatives (who provided some discretionary funding). The organization also engaged with the Delhi Jal Board, communicating that the requirement for tanker water would decrease once the tubewell was running (interview, 05/18/2012).

Initially, the NGO sent several workers to assess the everyday water realities of the camp. Over multiple visits to the area, the organization took stock of the camp's internal demography, differing social groups, local internal leaders, the uneven geographies of the built environment and available infrastructures. To increase the settlements' water flows and security, the NGO proposed to reactivate a dormant tubewell in the area that had fallen into disuse and disrepair over the last four years. By installing a three-phase electricity connection and a new motor, it was proposed by Fluidworks that the well would provide an internal piped system of groundwater for the community that could eventually replace, or at least curtail the need for, tanker deliveries. The NGO took an incremental approach, proposing to activate the tubewell, but leaving many of the details to be worked out in the future. According to the head of the NGO, it wanted to "go slow" and "ease people in" to the proposed changes, and to work with changing dynamics and obstacles on the ground.

Initially, Fluidworks engaged with women in the community to slowly form a women's "self-help" group to further the campaign. Notably, Hindu women were primarily approached to participate in the group (rather than Muslim women), possibly due to NGO workers' backgrounds and biases. Hindu women also tended to have higher levels of income that could be devoted to water, and time available to meet as compared with the sparser and relatively poorer population of Muslim women on the other side of the camp. The Hindu women who participated expressed the hope of being able to improve some of their daily struggles with water and sanitation. Fluidworks and the self-help group eventually reached an understanding that the women's collective would be in charge of pooling money to install not only a functioning motor for the tubewell, but a pipeline and 
or/spigots to those households who would initially invest Rs. 1000, and be willing to pay approximately Rs. 150 a month for the needed electricity to run the well. Due to the high initial investment (Rs.1000), residents who were more economically disadvantaged, particularly those from the Muslim side, faced obstacles in participating. However, the costs of insufficient state water (including lost income from missing work) tended to be much higher than the monthly fee of Rs. 150.

The women's group, in conjunction with the NGO's input, also appointed a local Hindu woman, Charu, ${ }^{5}$ to lead the community group. Fluidworks assured the women that Charu would ultimately be given charge of the key to the tubewell (once it was running), which was necessary to activate its motor and control the timings and lanes in which water would run through the settlement. By shifting residents' dependence from unpredictable and insufficient tankers to the regular supply of groundwater, and by requiring community members to fund their own piped connections and monthly bills for the tubewell, Fluidworks declared that community members, and women in particular, would have greater empowerment to solve their own water problems.

While the absence of the state was the stated raison d'etre for the water project, I demonstrate that instead of replacing the state, political assemblages associated with the SDSD campaign served to reconfigure the nodes and networks of both state and non-state regulatory milieus. Here, I draw from Allen and Cochrane's (2010) work on topological state power and what they term the "powers of reach." Rather than governance being conceptualized as vertical (top-down) or horizontal (emanating outwards), these scholars reveal how assemblages of both state and non-state actors exercise "powers of reach that enable them to be more or less present" (2010:1074) within institutional arrangements and political structures. Changes to the waterscape were accompanied by, and productive of, shifts in the powers of reach with regard to both state and informal political actors. In particular, the initiative ultimately served to displace and replace, as well as extend and limit, the reach and presence of particular political actors in the spaces of the state. Additionally, it provided a platform through which the presence and reach (Allen and Cochrane 2010) of particular nodes of the state became either strengthened or retracted in the spaces of the settlement, ultimately forging new formal and informal constellations of power and control over the local water supply. Ultimately, these political assemblages combined with everyday materialities of the waterscape to remap the uneven geographies of both water and power in the settlement.

Firstly, political assemblages associated with the SDSD campaign enabled the reach of particular NGO actors to increase substantially, furthering their presence within state spaces (Allen and Cochrane 2010). This occurred most overtly when the key sites and delivery of state water became altered within the settlement in early 2012. As noted earlier, prior to the SDSD campaign, the DJB provided one water tanker for each side of the settlement. However, as tubewell water began to run in the settlement, workers from Fluidworks directed the DJB to cut-back the frequency of tanker deliveries, as well as their delivery points. At one point, they directed the state tanker designated for the Muslim area to be delivered directly into a newly built underground storage tank in the middle of the settlement, which was physically located in the predominately Hindu area. This storage area was then designated to be a holding place where water could be continually kept underground. Although tanker water was temporarily redirected there, Fluidworks intended the underground storage area to eventually become a filling point for additional tubewell water to be placed as tankers were phased out. By changing the 
flow and storage of state tanker water, the NGO ultimately acted to remap the timing and flow of state water in Rampur Camp. ${ }^{6}$

One resident, named Laila, recounted the turn of events that led to the sudden stoppage of tanker water deliveries to the predominately Muslim side of the settlement, stating:

We used to get water from the DJB [tanker deliveries]. But then, there is a madam [Diya, from the NGO] who stopped it. She wants the underground tank on the other side [Hindu-side] to be filled up with our DJB tanker water. But people here refused the proposal. We don't want to drink that water [from an underground tank] because it gets contaminated and people defecate there as well. It is very dirty... Diya-madam then said that she would stop the tanker from coming, and she was threatening us. A few people then started arguing with her. So she said that she will complain to the DJB about us and make them stop the tanker deliveries (interview, 05/19/2012).

Laila went on to report:

It happened around four to five days ago. The tanker [driver] had come at around $4 \mathrm{pm}$ and he refused to give us water and started filling up the underground tank [on the Hindu side]. Then, people from both sides [of the settlement] gathered and protested and said that "we don't want to drink from that tank." The thing is, if the water is filled in the tank, they will start charging for the water there (Interview, 05/19/2012).

Here, in mobilizing political assemblages with the state, actors from the NGO deepened both their presence and reach into state institutions, altering the spatial and regulatory arrangements of water by retracting regular municipal tanker deliveries and instead channelling water into an underground storage area. This new political assemblage produced consequences that were felt most profoundly by the more marginalized Muslim-majority area of the camp. The Muslim side of the settlement was largely uninvolved with the women's self-help water group, nor could residents from this area easily afford the steep initiation fees required for tubewell water. When state tanker deliveries to their lanes were halted, Muslim residents were left without state water or access to the new tubewell infrastructure, barring them from a viable internal water source to turn to. In addition to these more extreme impacts, residents from all areas of the settlement protested the new spatiality of water storage and access, fearing that placing treated drinking water into an underground tanker near the spaces where children defecated would contaminate the water supply, as well as enable the water source to potentially be captured (and sold-off) by powerful actors in the settlement.

Secondly, new configurations of the presence and absence of key nodes of the state in the infrastructural regulatory spaces of the settlement eventually enabled a set of local strongmen to increase their political agency and control of water in the settlement. This new pathway of control occurred when the reach of particular state agents into the spaces of the camp changed as state officials were approached to finance portions of the new water supply. Such financing is achieved through the discretionary budgets of elected Councillors from the regional Municipal Corporations of Delhi and Members of the Legislative Assembly (MLAs). These state officials disperse allotted yearly budgets to flexibly fund infrastructural projects in their areas. They also frequently work in tandem with state bodies like the DJB, MCDs and Delhi Development Authority (DDA) in coordinating the timing and placement of funded infrastructures within settlements, including the installation of water pipes and the laying of roads. For example, in the past, the elected MLA for Rampur Camp had played a decisive role in determining the timing 
and placement of water tanker deliveries and had funded the laying of concrete for several lanes in the camp prior to 2011.

Fluidworks approached these elected politicians for funding new water infrastructures in Rampur Camp. When I questioned one of the NGO leaders about how discretionary funding was proposed, and eventually obtained, from key state actors, she commented:

What we understood was, we are not the vote bank for the politician. At best, we should be seen in the role of facilitator or direction-giver. It was the people who went there. We would facilitate the autos in which people would go, but the people went there (Interview, 05/18/2012).

Explaining the careful politics by which elected representatives (and their discretionary funds) are brought on board to the NGO's campaigns, the leader from Fluidworks went on to state:

To create a win-win situation you have to give each person what they want. With a political leader, what does she want? The reassurance that these people [from the community] will be with her when she needs them most. That means voting time. The respect that she thinks she deserves. And she does not want to be criticized when she comes into a public forum, and she wants to be appreciated, and she wants the opportunity to make money as well. We can't give her that money... [For example] in the process of making the road, they [the elected officials] made money. So now we had no role to play in that. We said, we don't ask any questions [about how the money is made], but at least residents get something out of that (ibid).

For the SDSD campaign, Fluidworks specifically deployed leaders and strongmen from the settlement to act as intermediaries who could carry the NGO's message and proposals for the new water system to local politicians. This arrangement enabled powerful local residents, such as the Pradhan (informal leader) and other strongmen, to broker deals directly with elected representatives (and potentially offer votes in exchange for waterworks) without the NGO's direct involvement. When the local MLA was approached to partially fund the new water infrastructure, he declined, instead choosing to channel his discretionary funds to a larger settlement with a more powerful vote-bank, where he had set up office and could be regularly seen walking the lanes. On the other hand, the South Delhi MCD Councillor, agreed to provide funding for the tubewell and motor. Critically, the contribution and presence and reach of the South Delhi MCD Councillor in funding the water project, alongside the notable absence of the MLA, enabled the Pradhan and his associated strongmen to become key political agents in the regulation of the settlement's water.

Critically, the Councillor insisted to Fluidworks that she would partially fund the tubewell only if the Pradhan, who had helped her in the past to secure community votes, was given control over the key to the tubewell motor. This resulted in the Pradhan strengthening his power, financial gain and spatial power over the new tubewell installation, granting him the ability to regulate the timings of when the tubewell would run, and to which lanes. In addition, this new political assemblage had the simultaneous effect of disempowering the women's collective, and its local leader, Charu, from the role in supervising the running of the well. This decision became justified by attributing the women's sudden exclusion to their illiteracy. In particular, the NGO lamented that it would be quite difficult for women to regulate the tubewell and billing without the written skills to keep accurate logs. Thus, gendered patterns of illiteracy became deployed as a political tool to justify the sudden exclusion of women from the participatory governance of water. When I questioned 
leaders at Fluidworks about the decision to give the Pradhan control of the key, the NGO director gave two reasons during an interview, elucidated in the following quotations:

[The South Delhi MCD Councillor] paid hard cash to get this borewell [tubewell] open. The only condition the Councillor gave was that the keys are given to the Pradhan. And that's why we are not treading too much [in that area]... That's the only condition the Councillor gave, and the Pradhan is also doing a good job so why [should we get too involved in that].

[The leader of the woman's group Charu] she is illiterate, so that is a big problem for us [...] because you know, there is a process that needs to be followed, and we are not able to keep track of what is happening. That is why the Pradhan here is a stronger figure. (Interview, 05/01/12)

Here, the materialities of the tubewell, gendered patterns of educational disadvantage and related discrimination, and the uneven reach of key state actors (through geographies of vote-bank politics) operated to bolster forms of informal authority in the camp. These shifts in constellations of governance over the local supply produced not only new patterns of power and control with regard to water infrastructure, but also transformed embodied practices and spaces associated with accessing the resource, to which I now turn.

\section{Uneven Embodied and Spatial Effects: The New Sites, Rhythms and Practices of Water}

31 This section of the paper traces how changes to the regulation and materiality of water produced new sites, rhythms and timings of residents' water practices. I show the diverse ways water is continually (re-)negotiated, embodied, and socially differentiated on the ground, revealing plural political agencies, subjectivities and outcomes within Rampur Camp. The water intervention both reinforced and altered particular social hierarchies in the community, producing changing axes of social power and difference in relation to everyday water governance. Ultimately, the SDSD initiative reconfigured power relations such that the water and social marginality of some of the most disadvantaged in the community actually worsened during the time of the study. Here the uneven geographies of water and power intersect, revealing socially differentiated forms of embodied practices, access and control that shaped the uneven experience of marginality and precariousness in the camp.

When the SDSD tubewell began running in the community, it had the overall effect of intensifying, rather than lessening, the overall spatial and social segregation of water in the settlement. The residents that experienced the most compounded forms of inequality and marginalization lived on the Muslim-side of the settlement. This group was excluded from participating in both the women's collective as well as the extension of piped infrastructure, despite experiencing comparatively higher levels of poverty, insecurity and overall need within the community. The reasons for their overall exclusion were multiple. Firstly, as decided by Fluidworks, the project itself was not designed to subsidize the poorest households, recruiting only those who could afford an initial investment of Rs.1000 to lay household pipelines/nearby spigots, and thereafter a regular monthly fee. As a result, women from the Muslim side of the community, whose numbers were fewer than on the Hindu side, were more reticent to join the women's group, and pipelines were not initially installed for this side of the settlement. Moreover Muslim men, who were key managers of everyday household water, had no platform through which to be directly 
included. When questioned specifically about the social and spatial exclusion of these residents, the director of Fluidworks blamed the Muslim community for its "lack of integration." She stated:

We try to get each area to have a representative, but we don't force fit anything. The Muslim side is very different. Integration is not happening. We don't force anything, it will grow over time. You will see that slowly already one water pipe has gone over to the other side. When our people work, when my women go, they talk to both sides. Because social dynamics have to be maintained, they go slow when people are not integrating (Interview, 05/01/2012).

The Pradhan used this pattern of exclusion as an opportunity to collect more money and increase his social power by controlling the timings and locations of water flows. While residents had informally elected the Pradhan more than a decade prior, when he brokered important deals with the police and other state agents to help allow settlers to build and remain located in the area, many residents expressed their current disgruntlement with him. He was perceived to have an ongoing drinking problem, paid for in part through minor scams of residents and connections to local state authorities. In addition, he was criticized by Muslim residents for largely neglecting their concerns, which manifested through the appearance of fewer infrastructures, pakka houses, and less help with getting ration cards and voter IDs for this group.

However, during the SDSD initiative, the Pradhan reached out to Muslim residents, offering to include them by setting up his own fee collection and payment structure for tubewell water. Promising a long-term piped connection, he regularly made visits to residents asking for payments of Rs. 50-100 to begin the installation process, only to return again to ask for additional sums to "problem solve" a variety of obstacles and hurdles to the installation. While residents did not trust the Pradhan, and were quite wise to his tactics, they also calculated that the risk of losing the money was worth the potential gain of being able to access some form of additional water. For Muslim men who lived alone, their work as labourers meant that even if tanker deliveries became more reliable, such water would likely be available only during work periods, making the resource highly inaccessible. Furthermore, small payments of Rs 50-100 were more affordable than the initial Rs 1000 and regular billing that were officially required by the SDSD campaign. However, these negotiations and interactions with the Pradhan became another means by which this community came to feel their compounded social, financial and infrastructural hardships. One Muslim man commented:

We have given him [the Pradhan] money a lot of times. He fills his own pocket with it. He always says that the money has been spent to buy pipes and other things (Interview, 02/21/12).

In a parallel vein, a Muslim woman living in the settlement stated:

All the work gets done on that [the predominately Hindu] side of the basti [informal settlement]. There is no development here... We gave all the money to the Pradhan and he does not get anything done (Interview, 02/16/12).

Another woman explained her perception of ethno-religious discrimination as being central to the segregated and unequal infrastructures in the camp:

It has been a very long time [that I have lived here]. Around 15 to 20 years. And still there is no development on this side, while there is a lot on the other... [because] most of the people here are Muslims, and also the Pradhan is there on the other side (Interview, 02/16/2012).

In August of 2012, nearly one year after the initiative started, one plastic pipeline had been connected from the Muslim-side to the tubewell, rather than the individuated 
household pipes and/or spigots that dotted the lanes of the predominately Hindu area. This sole pipe brought a slow trickle of water that Muslim residents took turns accessing in a long line. As multiple households and families had to queue for one access point that only ran when the Pradhan turned on the motor, the slow and scant water quantities left these residents in a suspended state of waiting-both for a slow trickle of water from the pipe, as well as the implementation of further infrastructure.

The disproportionate precariousness and social marginality of this ethno-religious group was further exacerbated through quests for alternate sources of water outside the settlement. New rhythms of access were time-consuming, physically exhausting, and inhibiting of other work and activities. Muslim men often walked for one hour or more to procure and haul non-potable water from a tubewell in a neighbouring area, boiling it in order to use for drinking. Others chose to instead purchase small containers of treated water, sometimes spending up to Rs. 40 , roughly half of the daily salaries of some of the poorest. One male resident commented that the precariousness of daily water was also difficult to cope with mentally, stating:

We don't get proper sleep because of water. We are always tense. We might have accidents because of lack of sleep (Interview, 11/15/2011).

Another resident described how the insecurity of the water supply exacerbated food insecurity, stating:

There are days when there is no water, and we don't even manage to cook food. We have to go outside [to a food vendor] to eat. Forget about bathing and washing clothes. It is very difficult (Interview, 11/14/11).

Ultimately, the embodied experiences of these residents' daily water practices intensified intersecting ethno-religious, classed and gendered forms of social marginality, exclusion, and resource scarcity amongst the most vulnerable in the community. Here gender and ethno-religious differences intersect with the material realities of the water supply, producing the most profound embodied hardships for Muslim men, a finding that substantively differs from the more normative findings in the gender and water literature.

A second set of residents who experienced highly situated embodied and material changes in relation to the water supply was a group of Hindu women. These women had either joined the women's self-help group directly, or signed up to pay for the tubewell water through the collective. Women's practices and subjectivities became re-shaped by their initial leadership in the project, their later exclusion from overseeing the well and collecting bills (due to their publicized illiteracy), and the new practices, rhythms and struggles associated with accessing non-potable water from open spigots in the lane. The shift in these Hindu women's lived experiences provides a view into the "fluidity" of their subject positions, referring to: 1.) the ways that subjectivities are shaped through everyday water practices and their meanings, and 2.) the ways that subjectivities are fluid and changing in nature (Simone 2010; Perera 2009), becoming transformed through encounters, events, strategies, and negotiations that re-configured gender, ethnoreligious and class intersections.

Women on the predominately Hindu side of the settlement had initially expressed enthusiasm at the prospect of gaining access to regular water deliveries through pipe points, and for the potential to become directly involved in regulating the community's water resources. The leader of the women's group, Charu, even decided to quit her day job as a construction labourer, in order to help organize and lead the local 
implementation of the water initiative. In the following quotations from two different occasions when the topic of female leadership came up, Charu describes why women are needed to enact social change, conveying a sense of optimism in shaping realities on the ground and navigating both gender and party politics:

If some man stands up for leadership, then he takes money, gathers all votes [for elected politicians] in the [settlement] and no work gets done. That's why around 10 to 15 women have joined in and we are doing this now (Interview, 11/01/11).

The ladies are working very hard and coordinating quite well. The men don't have a care in the world. Now that people are coming from the political parties, all they [the men] care for is liquor and money. But the ladies would be fighting for the basic necessities (Interview, 02/15/12).

This sense of optimism fuelled what Simone (2010) calls a "politics of anticipation." Women suggested in their informal conversations with me that improvements in the water supply might open up their time for other opportunities, and that daily routines might become significantly easier. At the same time, these women expressed feelings of increased control and agency in being able to make themselves heard, and to actively shape changes on the ground. This positive sentiment was particularly notable to me in 2011 because it differed significantly from my conversations in field visits during 2008 and 2009 with many of the same women. Earlier, I had rarely encountered women's expressions of optimism regarding enacting community change and improving the water supply.

However, women's political agencies became reconfigured when the Pradhan came unexpectedly into control of the key to the tubewell. About four months after the tubewell began running, women expressed to me a new and heightened sense of disenchantment and increased precariousness about their everyday circumstances. Despite actions to resist new patterns of water control in the settlement, one woman lamented:

All of the work and initiative for the water was made by ladies [in the women's group] and they [the NGO] forcefully took away the power from us [by giving the Pradhan the key]. What the Pradhan does now is give water to those who pay him bribes, while those who actually worked for it, do not get anything (Interview, $6 / 9 / 12)$.

In a similar vein, Charu, the leader of the women's group, went from feeling optimistic about quitting her day job and leading the women's group, to feeling her voice in the process had been stifled. During the time Charu came to know the Pradhan would be in charge of the key to tubewell, she stated:

Diya [from Fluidworks] gave [the Pradhan] the keys. Diya said, "I will get you the keys after some time." But later, she again told us to shut up and do things according to how she wants them done... So, I have stopped fighting for all this. What if I get beaten up? (Interview, 2/20/12).

As the Pradhan exploited a distinct political opening in the settlement's water regulation, he was able to control the flow of daily water in a much more extensive manner than previously possible when tankers had serviced the settlement. Not only did the Pradhan determine when, and if, the motor and tubewell would be activated during the day, he began regulating which lanes and spigots (installed outside groups of houses) received water at which times, with many households unable to fill water due to inadequate running time and water pressure. The limiting of water motor timings also allowed the Pradhan to pocket some portion of the funds collected for paying the electricity of the motor, as he ensured that water would run for far less time than budgeted for. It also 
allowed him to enforce forms of reward (for well-connected families, and those with the financial means to pay bribes) and punishment (for households that were not in the Pradhan's "good graces"). One resident recounted the new parameters of privileged water access:

People clean their vehicles with [tubewell water]... [The Pradhan] sells water to influential people, and Diya [from Fluidworks] tells me to give money to the Pradhan for water... [But] he has his own connection in his house [from the SDSD project] (Interview, 06/09/12).

The changes in the timings and flows of tubewell water became an ordinary tactic to privilege and marginalize particular residents and households, with the effect of further stratifying class distinctions. The Hindu households who began receiving disproportionately higher levels of access were those who were more socioeconomically advantaged-positioning themselves as important allies to the Pradhan and also providing small amounts of money and gifts to him.

41 Those Hindu women who did not gain privileged water access experienced changes to their everyday routines and rhythms. Instead of waiting for tanker water deliveries in the mornings, they waited throughout the day for the Pradhan to turn on the flow of water to their lane and spigot, which often produced a relatively scant and unpredictable flow of untreated water. On some days, the Pradhan failed to turn the well on. On other days, particular households would only get 15-20 minutes to try to fill buckets, despite water pressure often being so low that the time required to fill buckets for multiple families was easily three to four times as high. This meant that lanes in between houses became reinscribed as public spaces of struggle over accessing water from spigot points that were often shared by multiple houses, or that one person's "over-filling" would mean others in the lane would have less time and water pressure to fill. For example, one woman lamented:

There are fights every day. Some people get water while others don't. The flow of water in this lane is minimal as well. However, the flow is better in the other lane (Interview, 06/09/12).

Although previous tanker water deliveries had also entailed tension between neighbours (as residents tried to fill as many buckets as possible before the tanker became emptied), these moments of struggle were short-lived, and occurred outside the living areas and small lanes of the settlement. However, waiting for and filling water from spigots presented new spaces and timings of water that elongated daily tensions. As women waited for the Pradhan to turn on water for their lane, and for neighbours to fill their own buckets, competition over accessing sufficient quantities of water was intensified and often spread over entire afternoons within the small lanes of the settlement.

Adding further insult to injury, the quality of the groundwater from the tubewell was very poor. Community members complained about its salty taste and yellowish colour, preventing its use for drinking or cooking. When residents used the water for nonpotable purposes such as taking baths, they reported hair loss as well as new rashes and skin disorders. One resident summed up:

Now we have water for washing clothes and running our daily chores. But it is not fit for drinking. Also, we get rashes after taking a bath because of the salinity. If the DJB [Delhi Jal Board, the state water agency] water runs through the pipelines, the condition would be much better. We can't even cook with this water. The taste gets bad if food is cooked with this water (Interview, 05/19/12). 
This quotation further reveals a commonly-heard lament and aspiration: that if the Delhi Jal Board would extend its centrally-connected pipes to the area, many water problems would become solved. Certainly, with regard to cost, the price of DJB water is highly subsidized, with the current Aam Admi Party offering households with a legal meter connection the first 20 kilolitres of water per month free of charge (Delhi Jal Board 2016). Yet, if such an extension were to occur, it is questionable whether homes would be equipped with individuated meters or connections (as opposed to a community spigot). DJB water would, however, likely be of far better quality with regards to salinity and rate of contamination. By comparing the SDSD initiative with the aspired-for DJB piped water, this resident indicates the effects of the tubewell system in decreasing the availability of actual potable water, levelling a new set of embodied water-related hardships due to the erratic timings/pressure of accessing water, as well as the poor quality of the supply.

New problems of water quality and access resulted in women seeking out alternate sources of water for drinking and cooking purposes. Women's new gendered everyday rhythms required them to juggle being both homebound waiting for water to flow from the tubewell, while also needing to find creative ways to acquire potable drinking water through individualized tactics and networks. These included asking local employers for extra water, purchasing bottled water and extra fuel to boil water, and accessing water from neighbouring settlements. As one woman recounted:

Some women get water from [a nearby settlement]. A few get it from the households they work in. Everybody has to arrange it for themselves (Interview, 02/16/2012).

Individuated practices based on personal connections and calculations significantly impacted women's spatial mobilities and income-earning potentials, since the time and labour required to problem solve deficiencies bled into other aspects of everyday life. For example, a woman named Sunita decided to withdraw one of her girls from school so that the child could take over her own income-earning domestic work in a neighbouring middle class household. This tactic freed up Sunita herself to devote more of the day to problem-solving the water supply. These alterations of residents' everyday water practices produced new gendered, classed, and ethno-religious intersections in residents' subjectivities and unequal embodied experiences of the water supply.

\section{Conclusion}

Despite the diverse and unequal lived effects of the SDSD water improvement scheme, a number of widely circulated newspaper articles, videos, and media interviews publicized the success of the initiative in the settlement. One local woman recounted the divergence between residents' experiences and media representations, stating:

An oily layer forms on top of the water once it sits stagnant [in storage containers]. It's acidic... People have got rashes and become ill... [But] when the [new infrastructure] was installed, the media people came from $8 \mathrm{am}$ in the early morning so that they could record and publicize that all the problems have been solved (Interview, 06/07/2012).

This disjuncture points to a broader imperative to examine the micropolitics of water governance in unevenly shaping bodies, spaces and incongruent urban environments within (as well as between) settlements. 
47 By situating the multiple urban political ecologies of water in Delhi, this paper offers an account of the unique political assemblages that shape everyday water governance, and their uneven lived effects on the ground. First, my findings suggest that water governance is shaped by (re)configurations of particular nodes and networks of the state and other actors, which enable particular powers of reach and authority to be exercised in relation to water. Thus, this study works against the view that the state has uniformly withdrawn from illegal colonies, leaving a gap to be filled by NGOs and alternate providers of water. In Rampur Camp, the initiative ultimately served to both extend and limit the reach and presence of particular political authorities in the spaces of the state. It provided a platform through which the presence and reach of particular nodes of the state became either strengthened or retracted in the spaces of the settlement. However, it is also notable that such governance configurations can be difficult to predict in advance, and remain fluid rather than fixed. Over the course of tracking the water initiative from 2011-2012, control over differing water flows (tubewell and tanker water) changed hands multiple times, demonstrating the need to take a temporal view of everyday water practices and politics. ${ }^{7}$

In addition, by following the SDSD initiative as it unfolded in Rampur Camp, this research also elucidates the diverse ways that water governance is negotiated, embodied, and socially differentiated for city-dwellers. New governance configurations produced effects at various moments that ranged from being relatively beneficial, to intensifying exclusion and embodied hardships. For political actors such as the Pradhan, and residents with close personal ties to him, the water initiative provided an opening to alter the everyday power geometries of access in the community. Particular subject positions became associated with pockets of relative privilege, increased social power in the community, and exceptionalism to the normative rhythms, routines and struggles to access water. On the other hand, the majority of Hindu women experienced a temporally changing set of water-related consequences that, at times, furthered their political agencies and inclusion in the city, and later compounded embodied hardships. Although these women initially played a substantial role in controlling new water infrastructures, they later experienced an intensification of gendered embodied inequalities and exclusions related to the transformations of the control, rhythms and timing of water. Thus, my findings show the fluid ways that subjectivities become temporally transformed through waterrelated practices that locally re-configure axes of power and difference.

Lastly, while the gender and water literature normatively highlights the unequal gendered position of women with regard to water access and control, the results of this research were somewhat unusual in demonstrating the compounded gendered hardships of Muslim men. In the case of Rampur Camp, everyday materialities and power relations situate Muslim men with the highest levels of precariousness, marginality, and embodied physical consequences in relation to water access during the SDSD campaign. These findings suggest the need to give careful attention to dissecting how multiple subjectivities intersect, transform and become reproduced in the quest for water, rather than presupposing fixed patterns of power relations on the ground. Thus, there is a need to continue to examine and further pinpoint how water flows and social power are intertwined and unevenly distributed in the city, producing highly incongruent water worlds for residents in cities such as Delhi. 


\section{BIBLIOGRAPHY}

Allen, John and Allan Cochrane. 2010. "Assemblages of State Power: Topological Shifts in the Organization of Government and Politics.” Antipode 42(5): 1071-89.

Anand, Nikhil. 2011. "Pressure: The Politechnics of Water Supply in Mumbai." Cultural Anthropology 26(4): 542-64.

Bakker, Karen. 2011. "Commons Versus Commodities: Political Ecologies of Water Privatization." Pp. 345-68 in Global political ecology, edited by R. Peet, P. Robbins and M. Watts. New York: Routledge.

Bakker, Karen. 2003. “Archipelagos and Networks: Urbanization and Water Privatization in the South." The Geographical Journal 169(4): 328-41.

Baviskar Amita. 2003. "Between Violence and Desire: Space, Power, and Identity in the Making of Metropolitan Delhi." International Social Science Journal 55(175): 89-98.

Birkenholtz, Trevor. 2013. “'On the Network, Off the Map': Developing Intervillage and Intragender Differentiation in Rural Water Supply." Environment and Planning D: Society and Space 31(2): 354-71.

Birkenholtz, Trevor. 2010. “'Full-cost Recovery': Producing Differentiated Water Collection Practices and Responses to Centralized Water Networks in Jaipur, India." Environment and Planning A 42(9): 2238-53.

Björkman, Lisa. 2015. Pipe Politics, Contested Waters: Embedded Infrastructures of Millennial Mumbai. Durham: Duke University Press.

Coelho, Karen. 2006. “Tapping In: Leaky Sovereignties and Engineered (Dis)order in an Urban Water System." Sarai Reader 6: 497-509.

Comptroller and Auditor General of India (CAG). 2013. Report No. 2 of 2013 Government of Delhi, Report of the Comptroller and Auditor General of India on Social Sector. Government of India.

Cornea, Natasha, Anna Zimmer and Rena Véron. Forthcoming. "Power, Ponds, and Institutions: The Everyday Governance of accessing Urban Water Bodies in a Small Bengali Town." International Journal of Urban and Regional Research. doi: 10.1111/1468-2427.12377. (http:// www.ijurr.org/article/ponds-power-institutions-everyday-governance-accessing-urban-waterbodies-small-bengali-city/)

Daga, Shivani. 2003. "Private Supply of Sater in Delhi." Centre for Civil Society. Working Paper 59. Retrieved February 23, 2010 (www.ccsindia.org/ccsindia/policy/trans/studies/wp0059.pdf).

Datta, Ayona. 2012. The Illegal City: Space, Law and Gender in a Delhi Squatter Settlement. Farnham: Ashgate Publishing, Ltd.

Davis, Jennifer. 2004. "Corruption in Public Service Delivery: Experience from South Asia's Water and Sanitation Sector." World Development 32(1): 53-71.

Delhi Jal Board. 2016. “Water Connection.” Retrieved July 5, 2016. (http://www.delhi.gov.in/wps/ wcm/connect/doit_djb/DJB/Home/Customer+Section/Water/) 
Desai, Renu, Colin McFarlane and Steven Graham. 2015. "The Politics of Open Defecation: Informality, Body and Infrastructure in Mumbai." Antipode 47(1): 98-120.

Centre for Policy Research. 2015. “Categorization of Settlement in Delhi.” Research Report. Delhi: CPR.

Graham, Stephen, Simon Marvin. 2001. Splintering Urbanism: Networked Infrastructures, Technological Mobilities and the Urban Condition. Psychology Press.

Graham, Steven, Colin McFarlane, eds. 2014. Infrastructural Lives: Urban Infrastructure in Context. New York: Routledge.

Harris, Leila. 2009. "Gender and Emergent Water Governance: Comparative Overview of Neoliberalized Natures and Gender Dimensions of Privatization, Devolution and Marketization." Gender, Place and Culture 16(4): 387-408.

Heynen, Nik, Maria Kaika and Erik Swyngedouw, eds. 2006. In the Nature of Cities: Urban Political Ecology and the Politics of Urban Metabolism, London: Routledge.

Hosagrahar, Jyoti. 2010. "Landscapes of Water in Delhi: Negotiating Global Norms and Local Cultures." Pp. 111-32 in Megacities: Urban Form, Governance and Sustainability, edited by A. Sorensen and J. Okarta. Tokyo: Springer.

Hosagrahar, Jyoti. 1997. “Design, Domination and Defiance: Negotiating Urbanism in Delhi, 18571910." PhD dissertation, Department of Architecture, University of California, Berkeley.

Kaika, Maria. 2004. "Interrogating the Geographies of the Familiar: Domesticating Nature and Constructing the Autonomy of the Modern Home." International Journal of Urban and Regional Research 28(2): 265-86.

Keil, Robert. 2005. “Progress Report-Urban Political Ecology.” Urban Geography 26(7): 640-51.

Keil, Robert. 2003. “Urban Political Ecology 1.” Urban Geography, 24(8), pp. 723-38.

Kooy, Michelle. 2014. “Developing Informality: The Production of Jakarta's Urban Waterscape." Water Alternatives, 7(1).

Kooy, Michelle and Karen Bakker. 2008. "Splintered Networks: The Colonial and Contemporary Waters of Jakarta." Geoforum 39(6): 1843-58.

Laurie, Nina. 2005. "Establishing Development Orthodoxy: Negotiating Masculinities in the Water Sector." Development and Change 36(3): 527-49.

Lawhon, Mary, Henrik Ernstson and Jonathan Silver. 2014. "Provincializing Urban Political Ecology: Towards a Situated UPE through African Urbanism." Antipode 46(2): 497-516.

Loftus, Alex. 2012. Everyday Environmentalism: Creating an Urban Political Ecology, University of Minnesota Press.

Mann, Michael. 2007. “Delhi's Belly: On the Management of Water, Sewage and Excreta in a Changing Urban Environment during the Nineteenth Century." Studies in History 23(1): 1-31.

Maria, Augustin. 2006. “The Role of Groundwater in Delhi's Water Supply.” Pp. 459-70 in Urban Groundwater Management and Sustainability, edited by J. H. Tellam, M. O. Rivett, and R. G. Israfilov. Dordrecht: Springer.

McFarlane, Colin, Jonathan Silver and Yaffa Truelove. Forthcoming. "Cities within Cities: IntraUrban Comparison and Infrastructure in Mumbai, Delhi and Cape Town." Urban Geography.

O’Reilly, Kathleen. 2010. “Combining Sanitation and Women's Participation in Water Supply: An Example from Rajasthan.” Development in Practice 20(1): 45-56. 
O’Reilly, Kathleen. 2006. “'Traditional' Women, 'Modern' Water: Linking Gender and Commodification in Rajasthan, India." Geoforum 37(6): 958-72.

Pflieger, Geraldine and Sarah Matthieussent. 2008. "Water and Power in Santiago de Chile: Sociospatial Segregation through Network Integration." Geoforum 39(6): 1907-21.

Peluso, Nancy and Jesse Ribot. 2003. “A Theory of Access.” Rural Sociology 68(2): 153-81.

Perera, Nihal. 2009. "People's Spaces: Familiarization, Subject Formation and Emergent Spaces." Planning Theory 8: 51-76.

Ranganathan, Malini. 2014. "Paying for Pipes, Claiming Citizenship: Political Agency and Water Reforms at the Urban Periphery." International Journal of Urban and Regional Research 38(2): 590608.

Rocheleau, Diane, Barbara Thomas-Slayter and Esther Wangari. 2013. Feminist Political Ecology: Global Issues and Local Experience. New York: Routledge.

Sharan, Awadhendra. 2011. "From Source to Sink: 'Official' and 'Improved' Water in Delhi, 18681956." Indian Economic \& Social History Review 48(3): 425-62.

Sharan, Awadhendra. 2006. "In the City, Out of Place: Environment and Modernity, Delhi 1860s to 1960s." Economic and Political Weekly: 4905-11.

Sheikh, Shohana, Sonal Sharma and Subhadra Banda. 2015. The Delhi Jal Board: Seeing Beyond the Planned. Research Report. Delhi: Centre for Policy Research.

Silver, Jonathan. 2016. "Disrupted Infrastructures: An Urban Political Ecology of Interrupted Electricity in Accra." International Journal of Urban and Regional Research 39(5): 984-1003.

Simone, Abdoumaliq. 2010. City Life from Jakarta to Dakar: Movement at a Crossroads, New York: Routledge.

Sultana, Farhana. 2009. "Fluid Lives: Subjectivities, Gender and Water in Rural Bangladesh." Gender, Place and Culture 16(4): 427-44.

Swyngedouw, Erik. 2004. Social Power and the Urbanization of Water: Flows of Power, Oxford: Oxford University Press.

Truelove, Yaffa. 2015. “Gray Zones: Water, Power and Everyday Practice in Delhi, India.” PhD dissertation, Department of Geography, University of Cambridge.

Truelove, Yaffa. 2011. "(Re-)Conceptualizing Water Inequality in Delhi, India through a Feminist Political Ecology Framework.” Geoforum 42(2): 143-52.

Truelove, Yaffa and Emma Mawdsley. 2011. "Discourses of Citizenship and Criminality in Clean, Green Delhi." Pp. 407-25 in A Companion to the Anthropology of India, edited by I. Clark-Deces. Malden: Wiley-Blackwell.

Zérah, Maria-Hélène. 2000. Water: Unreliable Supply in Delhi. Delhi: Manohar.

Zérah, Marie-Hélène. 2008. "Splintering Urbanism in Mumbai: Contrasting Trends in a Multilayered Society." Geoforum 39(6): 1922-32.

Zimmer, Anna. 2015. “Urban Political Ecology 'Beyond the West': Engaging with South Asian Urban Studies.” Pp. 591-603 in The International Handbook of Political Ecology, edited by R. Bryan. Northampton: Elgar.

Zimmer, Anna. 2010. "Urban Political Ecology: Theoretical Concepts, Challenges, and Suggested Future Directions.” Erdkunde 64(4): 343-54. 


\section{NOTES}

1. In order to protect the anonymity of research participants, I have not provided the reference for the article, which explicitly names the settlement and its inhabitants. Contact author for further details.

2. Pseudonyms for the settlement, and its residents, have been used to ensure anonymity.

3. Pseudonyms for the NGO, as well as the names of its workers, have been used.

4. JJ clusters are one of eight different settlement types designated by the state in Delhi. Other illegal settlement types include unauthorized colonies, and non-notified slums (Center for Policy Research 2015).

5. Pseudonyms have been used for all names to protect confidentiality.

6. I was not able to get an answer from the DJB as to why they particularly complied with requests to change the timing and location of deliveries. However, as I have observed in my research in other areas of Delhi such as Unauthorized Colonies, it is relatively common to find particular political authorities playing key roles in determining tanker delivery positions and frequency, including MLAs and Municipal Councillors.

7. A follow-up research visit in 2016 revealed that the Pradhan continued to exercise control over the tubewell, but that tanker access had been relatively increased, with a group of residents reporting that some of their everyday water struggles had consequently reduced.

\section{ABSTRACTS}

In 2011, the "Swach Delhi Swasth Delhi" (Clean Delhi Healthy Delhi) campaign designated more than 20 settlements in the capital city to receive water and/or sanitation improvements. Tracing the water initiative in Delhi's Rampur Camp, this paper employs a situated approach to the urban political ecology of water in order to tease apart the variegated governance and lived experiences of its flows. Rather than the conventional reading of the state as having "withdrawn" from water governance in illegal colonies, my analysis reveals shifting state and non-state political assemblages as playing key roles in the everyday regulation of water in Delhi. First, I demonstrate that everyday governance is shaped by (re)configurations of specific nodes and networks of the state and other actors, which enable particular powers of reach and authority to be exercised in relation to water. Second, my findings detail the situated impacts of new governance configurations within urban spaces, revealing how water is (re-)negotiated, embodied, and socially differentiated on the ground. These findings further reveal the pathways by which situated and distributed forms of social and political power shape incongruent urban environments for the city's residents.

\section{INDEX}

Keywords: water, Delhi, situated urban political ecology, environmental politics, informality, infrastructure 


\section{AUTHOR}

\section{YAFFA TRUELOVE}

Assistant Professor, Urban Studies, Division of Social Sciences, Yale-NUS College 